RECFIV/FD

FEB 091994

\title{
Geologic Map of the Richiand 1:100,000 Quadrangle, Washington
}

Prepared for the UIS. Department of Energy Office of Erivironirnental Piestoration and Waste Management.

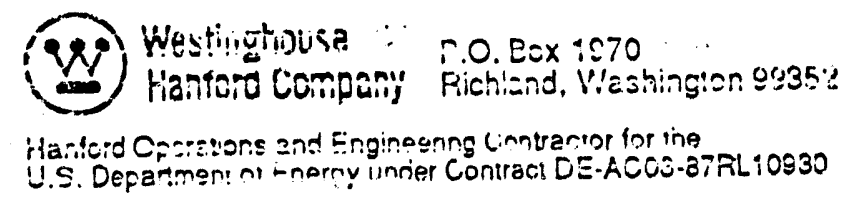




\section{LEGAL CISCLAIMIER}

This repor: was prepared as an account of work sponsoreo by an agunoy of the Unitec Slates Government. Neither tre

Uniiad Sia:es Gevornmen! nor any agency thereol, nor any of theif employece, ror any of the ren contactors, sibcortractors oi their emplo; ces, makes any warranty, express or impled. or sssumes any legal liabilley or responsibility ior the accuracy, completeness, or any thim party's use or the results of sush use of any intormaticn, apparalus, product, or process disclosed, or represents that its use would not intringe privately owned rights. Reterence herein 10 any specific commercial prosict, process or service by lrace name, trademark, manutaclurer, or otherwise ooes rol necessarily constlute or imply its endorsement, fecominendation. or lavgring by tha lirited Staies Governinent ur any augency thereof or its contractors or subcuitraciors. Tho views and npinions of authors expresseó hierein do riot hecessarily staie or reflect those of the Uniteo Stales Goveinment or any anency thereoi.

This report has been repreduced from the best avallable cony. Available in paper copy and microficiene.

Availabie to the U.S. Depariment of Energy and its contractors from

Olfice of Scientific and Technical Information

P.O. Box 62

Dak Hidge. TN 37831

(bi5) $576-8401$

Available 10 the public from the U.S. Depariment of Commerce Nationa! Technica! !nformation Sorvice

5285 Pon Roval Hoar

Springfielo VA 22101

(703) 487.4650

Pinted in the United States ol Amcita

OISCLN-1.THP $1.9:$ 


\title{
Geologic Map of the Richland 1:100,000 Quadrangle, Washington
}

\author{
S. P. Reidel
}

K. R. Fecht

Date Published

September 1993

Prepared for the U.S. Department of Energy

Office of Environmental Restoration and

Waste Management

\section{(W) Westinghouse P.O. Box 1970}

Hanford Company Richland, Washington 99352

Hanford Operations and Engineering Contractor for the

U.S. Department of Energy under Contract DE-AC06-87RL10930 


\title{
GEOLOGIC MAP OF THE RICHLAND 1:100,000 QUADRANGLE, WASHINGTON
}

\author{
compiled by
}

Stephen P. Reidel and Karl R. Fecht

\section{INTRODUCTION}

This map of the Richland 1:100,000-scale quadrangle, Washington, shows the geology of one of fifteen complete or partial 1:100,000-scale quadrangles that cover the southeast quadrant of Washington. Geologic maps of these quadrangles have been compiled by geologists with the Washington Division of Geology and Earth Resources (DGER) and Washington State University and are the principal data sources for a 1:250,000-scale geologic map of the southeast quadrant of Washington, which is in preparation. Eleven of these quadrangles are being released as DGER open-file reports (listed below). The map of the Wenatchee quadrangle has been published by the U.S. Geological Survey (Tabor and others, 1982), and the Moses Lake (Gulick, 1990a), Ritzville (Gulick, 1990b), and Rosalia (Waggoner, 1990) quadrangles have already been released.

The geology of the Richland quadrangle has not previously been compiled at 1:100,000 scale. Furthermore, this is the first 1:100,000 or smaller scale geologic map of the area to incorporate both bedrock and surficial geology.

This map was compiled in 1992, using published and unpublished geologic maps as sources of data. Except for Swanson and others (1980), source maps with scales smaller than 1:125,000 were not used. Maps produced before 1979 were not used as sources of data for the Columbia River Basalt Group because prior to that year mappers generally did not use geochemistry or magnetic polarity to confirm assignment of basalt flows to stratigraphic units, nor did they employ the stratigraphy that was proposed by Swanson and others (1979) and, with subsequent modifications, is universally used today. The lack of consistent, reliable identification procedures and standardized nomenclature makes it difficult to use pre-1979 maps unless one is personally familiar with the geology. However, as noted below, maps issued before 1979 were used as data sources for geologic units younger than the Columbia River Basalt Group.

These maps are included in an attempt to make the sources-of-data listing exhaustive and to inform the reader that these sources of data were not overlooked.

Unpublished geologic mapping by S.P. Reidel, and K.R. Fecht with assistance by M.A. Chamness for the entire map has been incorporated in this map.

Large-scale maps that show both bedrock and surficial geology were used to compile both bedrock and surficial geology. These maps are:

- sheet 5 of Grolier and Bingham (1971) (used for post-basalt geology and basalt outcrop areas; contacts between members of the Columbia River Basalt Group are from Myers and others (1979) and extensively modified by the authors based on unpublished mapping for this study. 
All K-Ar ages cited herein (Baksi, 1989; Tol an and others, 1989; McKee and others, 1977; Reidel and Fecht, 1987) were published after 1976, they are assumed to have been calculated using the decay and abundance constants adopted by the International Union of Geological Sciences in 1976 (Dalrymple, 1979). The actual constants used were not reported.

The geologic time scale devised for the "Correlation of Stratigraphic Units of North America (COSUNA)" project of the American Association of Petroleum Geologists (Salvador, 1985) is used in this report, with modifications: the 0ligocene-Eocene boundary is set at $35.7 \mathrm{Ma}$ (Montanari and others, 1985), and the Pleistocene-Pliocene boundary is set at $1.6 \mathrm{Ma}$ (Aguirre and Pasini, 1985).

\section{Acknowledgments}

N. A. Eberle, C. F. T. Harris, and K. G. Ikerd of the DGER cartographic staff and J. R. Christensen, J. M. Roloff, and K. M. Reed of the DGER editorial staff prepared final copy and provided editorial support. Support for Reidel was provided by US Department of Energy, Office of Basin Energy Sciences grant number DE-FG06-91ER14172 to S. P. Reidel at Washington State University.

\section{DESCRIPTIONS OF MAP UNITS}

\section{Sedimentary Deposits and Rocks}

Quaternary Sedimentary Deposits

Qd

Dune sand (Holocene)--Eolian medium to fine sand and silt; grains composed of quartz, basalt, or feldspar; volcanic ash common; active and stabilized dunes occur in the west and northwest part of the map area; age inferred from geomorphology and ages of parent materials. Description compiled from: Grolier and Bingham, 1971; Myers and others, 1979; Rigby and others, 1979.

Qda Active sand dunes.

Qds Satbilized sand dune deposits.

Qa

Alluvium (Holocene to Pleistocene)--Clay, silt, sand, and gravel deposits of varied thickness and sorting; varied composition, commonly including reworked loess, Ellensburg Formation sediments, and basalt; includes Mazama tephra at numerous places; occurs in valley bottoms throughout the map area; age inferred from geomorphology, ages of parent materials, and the presence of Mazama tephra (about $7 \mathrm{ka}$; Kittleman, 1973, p. 2958). Description from Myers and others, 1979. 
Mass-wasting deposits (Holocene to Pleistocene)--Landslide deposits, talus, and colluvium; found at the base of slopes and on lower parts of slopes; age inferred from geomorphology, stratigraphic position, and ages of parent materials. Description compiled from: Grolier and Bingham, 1971; Myers and others, 1979; Rigby and others, 1979.

Q1

Loess (Holocene to Pleistocene)--Eolian silt and fine sand; tan to gray tan to pale orange; grain size decreases to the northeast; includes tephra beds, caliche layers, and paleosols; thickness as much as $75 \mathrm{~m}$ near St. John and Wilcox northeast of the map area (Ringe, 1970); uppermost loess locally contains Mazama tephra (Foley, 1982, p. 90), about 7 ka (Kittleman, 1973, p. 2958); paleomagnetic measurements show that the oldest loess was deposited during the Matuyama Reversed polarity epoch and is at least $730 \mathrm{ka}$ and probably $1 \mathrm{Ma}$ or older (McDonald and Busacca, 1989, p. 338). Includes Palouse Formation. Description compiled from: Grolier and Bingham, 1971; Myers and others, 1979; Rigby and others, 1979.

Qta

Talus (PIjocene to Recent)

Qaf

Alluvial fans (Holocene to Pleistocene)--Sand and gravel of varied 1ithologies; formed where intermittent tributary streams enter the valley of a master stream; generally cone-shaped; in places overlain by loess; located at the margins of modern stream valleys in the Snake River and along the Columbia River in the southwest corner of the map area; age inferred from geomorphic form and ages of parent materials; those fans located at elevations below the maximum elevation of glacial Lake Missoula outburst flooding are younger than the outburst flood deposits and are, therefore, Holocene; those located above the maximum elevation of glacial Lake Missoula outburst flooding are Holocene or older. Description compiled from: Myers and others, 1979; Rigby and others, 1979.

Qfs

Outburst flood deposits, consists of two facies - silt and sand; (Pleistocene)--Lacustrine silt and fine sand; predominantly quartz and feldspar; rhythmically bedded, with stringers of coarse-grained sand and gravel, small-scale cross-bedding, ice-rafted cobbles, and ice-melt structures present locally; sand dominated facies - plane lamination, occasional channel fill sequences, silt dominated facies - planar laminated and ripple cross laminated, commonly displaying normal graded rhymites; discrete ash layers common; divided into 4 time stratigraphic units based on magnetic polarity, presence of ash beds, pedogenic carbonate development, and stratigraphic position; deposited by outburst floods from glacial Lake Missoula and found along the Snake and Columbia Rivers and to elevations of approximately 1,200 $\mathrm{ft}$, but generally not extensive above about $900 \mathrm{ft}$; up to $6 \mathrm{~m}$ thick west Cold creek flood bar and south of Gable Mountain; thought to be younger than about $19 \mathrm{ka}$ and older than about $11 \mathrm{ka}$ on the basis of ${ }^{14} \mathrm{C}$ determinations that constrain the ages of advance and retreat of the Columbia lobe in southernmost 
British Columbia (Waitt, 1980, p. 675); additionally, Mount St. Helens S tephra, with an isotopic age estimate of $13 \mathrm{ka}$ (Mullineaux and others, 1978, p. 178), occurs below the top of the unit (Waitt, 1980, p. 667). Consists of the Touchet Beds. Description compiled from: Grolier and Bingham, 1971; Myers and others, 1979; Rigby and others, 1979.

$\mathrm{QfS}_{4}$

Younger outburst flood deposits from ice dams in Canada. Glacier Peak ash found in some areas.

$\mathrm{Qfs}_{3}$

Normal polarity; contains Mt. St. Helens Set S ash.

$Q f s_{2}$

Normal polarity, U/Th age date of $200 \pm 70 \mathrm{ka}$, capped by pedogenic carbonate development (stage III or IV).

Qf

01dest outburst deposits; reversed magnetic polarity, age $770 \pm 20 \mathrm{ka}$ based on magnetic polarity.

Qfg

Outburst flood deposits, gravel (Pleistocene)--Gravels; clasts range from sand to boulders, size generally decreasing away from major Missolla flood current channels; clasts chiefly basalt, but include granite, quartzite, diorite, and porphyries; divided into 4 time stratigraphic units based on magnetic polarity, presence of ash beds, pedogenic carbonate development, and stratigraphic position; deposited by outburst floods from glacial Lake Missoula and display numerous bedding forms and large flood bars; found along the Snake and Columbia Rivers; same age as outburst flood deposits, silt and sand (unit Qfs above) and correlative with Touchet Beds. Description compiled from: Grolier and Bingham, 1971; Myers and others, 1979; Rigby and others, 1979; this report.

$\mathrm{Qfg}_{4}$

Younger outburst flood deposits from ice dams in Canada. Glacier Peak ash found in some areas.

$\mathrm{Qfg}_{3}$

Normal polarity; contains Mt. St. Helens Set $S$ ash.

$\mathrm{Qfg} \mathrm{fg}_{2}$

Normal polarity, U/Th age date of $200 \pm 70 \mathrm{ka}$, capped by pedogenic carbonate development (stage III or IV).

Qfg, 
WHC-MR-0441

01dest outburst deposits; reversed magnetic polarity, age $770 \pm 20 \mathrm{ka}$ based on magnetic polarity.

$$
\text { Quaternary-Tertiary Sedimentary Deposits }
$$

QMg [QTg]

Sandy silty gravel (Quaternary-Tertiary), sandy, silty gravel; gravel mainly rounded with angular basaltic pebbles, consists of quartzose, volcanic porphy and basaltic clasts supported by quartzose-feldspathic basaltic sand matrix; poorly sorted; fine-grained sand matrix; massive to poorl graded bedding; large scale forset beds in upper part of unit suggesting it was reworked by Pleistocene floods; capped by poorly cemented pedocenic carbonate cap containing filled root tubes and burrows; up to 4 meters thick; confined to area between Benton City and Richland; may correlkate with Ringold Formation but uncertain; fluvial deposits by Columbia River based on lithology; description from this report.

$Q P_{L} g$

Gravel (Pleistocene to P1iocene), quartzose to gneissic clast-supported, rounded gravel with mediun-grained, micaceous quartzose-feldspathic sand matrix; includes quartzose-feldspathic fluvial sand facies and silty overbank facies; best exposed west of Richland; up to $25 \mathrm{~m}$ thick; confined to Pasco Basin principally between Gable Mountain and west of Richland; may be correlative with "Early Palouse soil" between Rattlesnake Hills and Umtanum Ridge; age is post-Pasco Basin incision at the end of Ringold time and perearliest known Pleistocene flood deposit ( $>1 \mathrm{Ma}$ and $\ll 3 \mathrm{Ma})$; deposited by Columbia and Yakima Rivers based on lithology; description from this report.

\section{Tertiary Sedimentary Deposits}

\section{Ringold Formation}

The Ringold Formation consists of fine and coarse, semi-indurated, fluvial and lacustrine deposits in and near the Pasco Basin (Fecht and others, 1987; Lindsey, 1991). In the Richland 1:100,000 quadrangle this unit crops out along the Columbia and Snake Rivers. The formation is as thick as $185 \mathrm{~m}$ in the deepest part of the Cold Creek syncline at the Hanford Site. The unit is overlain by unconsolidated Pliocene-and Pleistocene deposits and underlain by the Ice Harbor Member of the Saddle Mountains Basalt (Fecht and others, 1987), which was dated at $8.5 \mathrm{Ma}$ by Mckee and others (1977). At the White Bluffs north of Pasco, the lower $20 \mathrm{~m}$ of the Ringold has normal magnetic polarity, and the upper $100 \mathrm{~m}$ has reversed polarity (Rigby and others, 1979, p. 16). Microtine (rodent) fossils and magnetic polarity data indicate that the unit is older than $3.4 \mathrm{Ma}$ (Fecht and others, 1987). Two facies are shown on the map: finer deposits $\left(P_{L}, A C\right)$ and coarser sediments, chiefly conglomerate $(P, A c g)$. Exposed along flanks of anticlinal ridges and east side of the Columbia River in map area. 
Continental sedimentary deposits (Pliocene to Miocene)--Interbedded white, gray, green, red, or tan sand, silt, and clay beds with local pebble lenses and stringers; silty clay units horizontally laminated and generally lacking current-generated sedimentary structures; silt and sand units display horizontal, ripple, and cross bedding; sand chiefly quartz and feldspar; commonly capped by caliche; contains diatomite beds, ash beds, and fossils. Exposed along the east side of the Columbia River and in Snively Basin area (SW $1 \backslash 4 \mathrm{sec} .5$, T11N, R24E \& SE $1 \backslash 4 \mathrm{sec} .4$, T11N, R24E). Consists of the finer facies of the Ringold Formation. Description compiled from: Myers and others, 1979; Rigby and others, 1979; this report.

\section{$P_{L}$ Acg}

Conglomerate (Pliocene to Miocene)--Varicolored pebble to cobble conglomerate with sand matrix; clasts well rounded and chiefly composed of quartzite, granite, basalt, metamorphic rocks, and porphyritic volcanic rocks; generally massively bedded with some imbrication; includes lenses of coarse to medium quartz and feldspar sand that are cross bedded or foreset bedded in places; commonly uncemented, but in places moderately to poorly indurated with silica, iron oxide, and calcite. Consists of the conglomeratic facies of the Ringold Formation. Exposed along east side of Columbia River. Description compiled from: Myers and others, 1979; Rigby and others, 1979.

\section{Tertiary Volcanic Rocks}

\section{Columbia River Basalt Group}

The Columbia River Basalt Group in Washington is composed of four formations. From top to bottom they are the Saddle Mountains Basalt, the Wanapum Basalt, the Grande Ronde Basalt, and the Imnaha Basalt. The upper three formations crop out in the Richland 1:100,000-scale quadrangle.

Saddle Mountains Basalt

$\mathrm{Av}_{\text {sih }}$

Ice Harbor Member (upper Miocene)--Basalt flows, vents, northwest-trending feeder dikes, and minor tephra; plagioclase phenocrysts commonly more tabular (needlelike in cross section) than in other Saddle Mountains Basalt flows; less than $30 \mathrm{~m}$ thick in most places; flows crop out at Ice Harbor Dam and in the southcentral part of map area, about $8.5 \mathrm{Ma}$, based on $\mathrm{K}-\mathrm{Ar}$ age estimates (Mckee and others, 1977); consists of three informal units (Swanson and others, 1980; Swansor, and Helz, 1979), from youngest to oldest, basalt of Goose Island, basalt of Martindale, and basalt of Basin City, described by Myers and others (1979) and Swanson and others (1980) as follows:

Basalt of Goose Island--Dark gray, tan-weathering basalt flows with scattered phenocrysts of plagioclase (2-10 mm long), pyroxene $(2 \mathrm{~mm}$ long), and olivine and magnetite (less than $5 \mathrm{~mm}$ across); plagioclasepyroxene glomerocrysts $1.3 \mathrm{~cm}$ in diameter; microvesicular entablature with brick-bat jointing; well-formed colonnade with 0.5-1.5-m-diameter columns; low-latitude normal (transitional) magnetic polarity (Choiniere 
and Swanson, 1979); crops out near and a few miles northwest of Ice Harbor Dam; feeder dikes near Ice Harbor Dam, near Reese in the Walla Walla River valley, and in Esquatzel Coulee.

Basalt of Martindale--Two or more, black to gray, reddishweathering, fine- to medium-grained, vesicular to microvesicular basalt flows with sparse to abundant augite, plagioclase, and olivine phenocrysts; locally abundant glomerophyric clots of plagioclase and augite $20 \mathrm{~mm}$ or more in diameter; lower flow has a thick scoria top and a well-developed entablature overlying a poorly developed colonnade with columns as much as $1.5 \mathrm{~m}$ in diameter; reversed magnetic polarity (Choiniere and Swanson, 1979); upper flow or flows are less phyric and lack glomerophyric clots (Swanson and Helz, 1979); crops out near Ice Harbor Dam and southcentral part of map area; dikes and vents upstream and downstream of Ice Harbor Dam. A vent for the basalt of Martindale has been located south of the Olympic-Wallowa lineament on line with other Martindale vents (Reidel and Tolan, written comm., 1993).

Basalt of Basin City--Gray to black, fine-grained basalt flows; plagioclase phenocrysts generally less than $10 \mathrm{~mm}$ wide; plagioclase glomerocrysts as much as $2 \mathrm{~cm}$ in diameter; 01 ivine phenocrysts; no clinopyroxene phenocrysts; normal magnetic polarity (Choiniere and Swanson, 1979); feeder dikes occur just south of the Eagle Lakes on the eastern end of the Saddle Mountains.

$\mathrm{MV}_{\text {sem }}$

Elephant Mountain Member (upper Miocene)--Two nearly aphyric basalt flows (Swanson and others, 1980) with normal to transitional magnetic polarity (Rietman, 1966; Choiniere and Swanson, 1979; Reidel and Fecht, 1981) and an average total thickness of about $30 \mathrm{~m}$ but reaches 50 meter in corehole in cold Creek syncline and thins on ridges (Reidel, 1984; Reidel and Fecht, 1981; Reidel and others, 1989b); present throughout the map area; isotopically dated at $10.5 \mathrm{Ma}$ by McKee and others (1977) and at $9.4+/-0.7 \mathrm{Ma}$ and $10.7+1-0.8$ Ma by Stoffel (1984).

Upper flow (Ward Gap flow) black; weathers reddish brown; fine- to coarse-grained, locally diktytaxitic and generally coarser grained than lower flow; abundant microphenocrysts of plagioclase; vesicular flow top; thin entablature; well-developed colonnade with columns as much as $2 \mathrm{~m}$ in diameter; vesicle sheets that cause platy jointing; locally pillowed base (Myers and others, 1979).

Lower flow (Elephant Mountain flow) black to dark gray; weathers reddish gray; fine-grained to glassy, locally diktytaxitic; felty texture caused by abundant plagioclase microphenocrysts; thick, locally tiered entablature caused by horizontal vesicle sheets; well-developed colonnade with 1.0- to 2.0-m-diameter columns; local pillows and vesicle cylinders (Myers and others, 1979).

$\mathrm{MV}_{\mathrm{sp}}$

Pomona Member (middle Miocene)--Basalt, with small phenocrysts of plagioclase (generally less than $5 \mathrm{~mm}$ long), clinopyroxene, and olivine; plagioclase phenocrysts commonly wedge-shaped; locally contains large clots (as much as $100 \mathrm{~mm}$ or more across) of plagioclase, pyroxene (including very rare 
hypersthene), and olivine thought by Swanson and others (1980) to have formed during crystallization after eruption; reversed magnetic polarity (Choiniere and Swanson, 1979; Reidel and others, 1984); occurs as more nearly sheet-like flow(s); average thickness in map area is about $30 \mathrm{~m}$ but reaches $60 \mathrm{~m}$ in Cold Creek syncline and thins onto ridges (Reidel, 1984; Reidel and Fecht, 1981; Reidel and others, 1989b); isotopically dated at $12 \mathrm{Ma}$ (K/Ar method) by McKee and others (1977) and $12 \mathrm{Ma}\left({ }^{40} \mathrm{Ar} /{ }^{39} \mathrm{Ar}\right.$ method) (S. P. Reidel, Wash. State Univ., unpublished data, 1991). Description from Swanson and others, 1980.

Myers and others (1979) describe two flow units. Upper flow: black to gray-black; weathers gray; fine- to medium-grained; phyric with plagioclase and olivine phenocrysts as much as $5 \mathrm{~mm}$ across; locally microvesicular to diktytaxitic; well-developed entablature, generally with fanning columns; poorly to well-developed colonnade of 1-m-diameter columns. Lower flow: blue-black; weathers black-gray; fine- to medium-grained; plagioclase phenocrysts as much as $1 \mathrm{~cm}$ across; sparse olivine phenocrysts as much as 0.5 $\mathrm{mm}$ across; glomerocrysts of plagioclase and pyroxene as much as $2 \mathrm{~cm}$ across; well-developed entablature; hackly jointing and fanning columns.

$M v_{\text {se }}$

Esquatzel Member (middle Miocene)--Basalt flows; blue-black; weathers brownish; fine grained, plagioclase phyric to glomerophyric as much as $1.5 \mathrm{~cm}$ across; locally diktyxtaxtic with vesicle pipes and sheets; well developed entablature with hackly jointing; well developed colonnade with 1 m diameter columns; normal magnetic polarity (Choiniere and Swanson, 1979; Reidel and Fecht, 1981); greatest thickness is $30^{\circ} \mathrm{m}$ in coreholes in Cold Creek syncline but thins and pinches out onto anticlinal ridges (Reidel and Fecht, 1981; Reidel and others, 1989b); restriced to central and northern parts of map area; crops out on Gable Mountain and Gable Butte; older than the Pomona Member (McKee and others, 1977) and younger than the Asotin Member (13 Ma, Reidel and Fecht, 1987, p. 666); no known feeder dikes but presence in Snake River canyon suggests vent area near Clarkston, Washington; consists of at least two flow units (Reidel and Fecht, 1981); can easily be distinguished by higher $\mathrm{TiO}_{2}$ and $\mathrm{P}_{2} \mathrm{O}_{5}$ than overlying Pomona Member and underlying Asotin Member. Descriptions from Reidel and Fecht (1981), Swanson and others, (1979); Myers and others, (1979).

$M v_{\text {sa }}$

Asotin Member (middle Miocene)--Basalt flow; black to grey; weathers grey; glassy, fine- to medium-grained; aphyric with microphenocrysts of olivine up to $0.05 \mathrm{~cm}$ and rare plagioclase phenocrysts; locally ophitic and diktytaxitic; well-developed entablature with hackly.jointing and fanning columns; well developed colonnade with columns as much as $1 \mathrm{~m}$ in diameter; normal magnetic polarity (Choiniere and Swanson, 1979; Reidel and Fecht, 1981); no thicker than $30 \mathrm{~m}$ in map area; pinches out to south onto constructive topography of the Esquatzel Member and thins onto Umtanum Ridge (Reidel and Fecht, 1981; Reidel and others, 1989b); restricted to extreme northern part of map area; crops out on Gable Mountain; younger than underlying Wilbur Creek Member and older than overlying Esquatzel Member; no know feeder dike but present as far east as Idaho; locally mixed with Wilbur Creek Member and basalt of Lapwai to form Huntzinger flow indicating nearly. simultaneous eruption of the three flows (Reidel and Fecht, 1987). Descriptions from Reidel and Fecht (1981; 1987), Swanson and others (1979); Myers and others (1979). 
$M V_{\text {WC }}$

Wilbur Creek Member (middle Miocene)--Basalt flow;black to blue-black; weathers grey-black; fine- to medium-grained; aphyric with rare microphenocrysts of plagioclase; thin entablature with well-developed colonnade with columns 0.5 to $1.0 \mathrm{~m}$ in diameter; locally developed har.kly jointing and pillows at base of flow; normal magnetic polarity (Choiniere and Swanson, 1979; Reidel and Fecht, 1981); approximately $10 \mathrm{~m}$ thick in map area; exposed only on Umtanum Ridge as part of intracanyon flow along flow front of Umatilla flow (Reidel and Fecht, 1987); younger than underlying Umatilla Member and older than overlying Asot in Member; no know feeder dike; locally mixed with Asot in Member and basalt of Lapwai to form Huntzinger flow indicating nearly simultaneous eruption of the three flows (Reidel and Fecht, 1987). Descriptions from Reidel and Fecht (1981; 1987), Swanson and others (1979); Myers and others (1979).

MV

Umatilla Member (middle Miocene)--Basalt flows; black; weathers yellow-orange; glassy to very fine grained; locally medium-grained; sparse plagioclase phenocrysts as much as $0.7 \mathrm{~cm}$ across; we11-developed entablature (normal1y 80 percent of flows) with hackly jointing; local colonnade; normal magnetic polarity (Rietman, 1966); reaches $60 \mathrm{~m}$ thick in Cold Creek syncline but thins onto anticlinal ridges (Reidel and Fecht, 1981; Hagood, 1986: Reidel and others, 1989b) present throughout map area; older than Asotin Member (13 Ma, Reidel and Fecht, 1987, p. 666) and younger than Priest Rapids Member (14.5 $\mathrm{Ma}, \mathrm{Tol}$ an and others, 1989). Consists of an upper subunit called the basalt of Sillusi and a lower subunit called the basalt of Umatilla, which has lower $\mathrm{P}_{2} \mathrm{O}_{5}$ and higher $\mathrm{TiO}_{2}$ contents than the basalt of Sillusi; two flows are known to physically mix in map area (S. P. Reidel, Wash. State Univ., written commun., 1990). Description compiled from: Reidel and Fecht, 1981; Myers and others, 1979; Swanson and others, 1980.

Wanapum Basalt

$\mathrm{MV}_{\text {wpr }}$

Priest Rapids Member (middle Miocene)--Basalt flows; black, weather rusty brown; fine- to medium-grained, aphyric; diktytaxitic; 10cal diabasic texture in top flow; lower flows generally coarser grained than upper flow; scattered but prominent plagioclase phenocrysts generally less than $5 \mathrm{~mm}$ long but rarely as much as $10 \mathrm{~mm}$ long; olivine phenocrysts 0.5 to $1 \mathrm{~mm}$ in diameter; welldeveloped colonnade with 0.5-1.5-m-diameter columns; upper flow with wel1developed, hackly jointed entablature; reversed magnetic polarity (Rietman, 1966); total thickness upto $70 \mathrm{~m}$ in Cold Creek syncline but thins onto anticlinal ridges (Reidel and others, 1989b; Hagood, 1986); present throughout map area; isotopic age $14.5 \mathrm{Ma}$ (Tolan and others, 1989). Upper flow is designated the basalt of Lolo and the lower flows the basalt of Rosalia; the Lolo has higher $\mathrm{MgO}$ and lower $\mathrm{TiO}_{2}$ contents than the Rosalia (Swanson and others, 1979, p. G11, G37). Description compiled from: Reidel and Fecht, 1981; Myers and others, 1979; Swanson and others, 1980. 
$\mathrm{Av}_{\mathrm{wr}}$

Roza Member (middle Miocene)--Basalt flow(s); gray-black, weather reddishbrown; fine- to medium-grained; consistently contains several percent discrete (in places clotted) plagioclase phenocrysts averaging nearly $10 \mathrm{~mm}$ across; locally diktytaxitic; well-developed colonnade with columns as much as $1 \mathrm{~m}$ in diameter; columns locally pinch and swell; one or two flows in the map area but as many as seven flows near vents to the east of the map area (Swanson and others, 1975); transitional to reversed magnetic polarity (Choiniere and Swanson, 1979); average thickness about $30 \mathrm{~m}$; reaches $60 \mathrm{~m}$ in Cold Creek syncline but thins onto anticlinal ridges (Reidel and Fecht, 1981; Hagood, 1986; Reidel and others, 1989b) present throughout the map area; older than Priest Rapids Member (14.5 Ma, Tolan and others, 1989) and younger than Frenchman Springs Member (15.3 Ma, Tolan and others, 1989). The Roza Member, because of its ?arge and nearly ubiquitous plagioclase phenocrysts and wide distribution, is a key marker across much of the Columbia Basin. Dascription compiled from: Reidel and Fecht, 1981; Martin, 1989; Myers and others, 1979; Swanson and others, 1980. 
$M V_{\text {wfs }}$

Frenchman Springs Member (middle Miocene)--Five or more basalt flows; second lower flow(s) (basalt of Ginkgo) generally more phyric than middle and upper flows; normal to excursional magnetic polarity (Figure 5); thickness as much as $230 \mathrm{~m}$ in the Cold Creek syncline; flows thin and pinchout onto anticlinal ridges (Reidel and Fecht, 1981; Hagood, 1986); Reidel and others, 1989b); present in most of the map area; feeder dikes east of the map area; isotopic age 15.3 Ma for basalt of Sand Hollow, a flow in the middle of the member (Tolan and others, 1989); Beeson and others (1985) defined the informal Frenchman Springs subunits shown on Figure 5. Aphyric flows: gray-black; fine grained; well-developed entablatures with hackly jointing; colonnades with 1.5-2.0-m-diameter columns; locally pillowed bases. Phyric flow(s): gray-black; weather reddish-gray; fine- to medium-grained; abundant plagioclase phenocrysts and glomerocrysts; thin entablature; well-developed colonnade with 0.5-1.5-m-diameter columns. Description compiled from: Myers and others, 1979; Reidel and Fecht, 1981; Swanson and others, 1980.

\section{Grande Ronde Basalt}

The middle Miocene Grande Ronde Basalt makes up 87 percent of the volume of the Columbia River Basalt Group. Flows of the Grande Ronde Basalt are generally aphyric and fine grained. The groundmass contains plagioclase, augite, and pigeonite. Plagioclase phenocrysts are sparse, and microphenocrysts of orthopyroxene, pigeonite, and olivine are rare. Blocky jointing is common, but entablature and columnar jointing are also present. At least 120 flows are known; these are divided into 17 informal units (Reidel and others, $1989 \mathrm{a}, \mathrm{p} .23,36$; Fig. 5). In the Blue Mountains, east of the map area, the Grande Ronde has a maximum aggregate thickness of more than $1,235 \mathrm{~m}$, and the maximum thickness exposed at a single locality is about $1,050 \mathrm{~m}$. The formation is divided into four magnetostratigraphic units, but only are the two upper units exposed in the map area. The $\mathrm{N}_{2}$ magnetostratigraphic unit is exposed along the north face of the Saddle Mountains, Frenchman Hills, and Umtanum Ridge. Feeder dikes are exposed to to the east. The Grande Ronde conformably overlies the Imnaha Basalt, and it is overlain by the Wanapum Basalt, commonly with an intervening saprolite or sedimentary interbed. The formation is isotopically dated at about 15.6 to $16.9 \mathrm{Ma}$ (Baksi, 1989, p. 109; age information summarized by Reidel and others, 1989a, p. 24-25). The type locality is in the canyon of the Grande Ronde River north of the mouth of Joseph Creek (secs. 21-23, T. 7 N., R. 46 E.) in the Clarkston 1:100,000-scale quadrangle (Reidel and others, 1992).

$$
\begin{array}{ll}
\mathrm{Av}_{\mathrm{gN} 2} & \text { Upper flows of normal magnetic polarity. } \\
\mathrm{Av}_{\mathrm{gR2}} & \text { Upper flows of reversed magnetic polarity. }
\end{array}
$$

Description compiled from: Reidel, 1983; Hooper and others, 1985; Reidel and others, 1989a; Swanson and others, 1980; Swanson and Wright, 1983.

\section{REFERENCES CITED}


Aguirre, Emiliano; Pasini, Giancarlo, 1985, The Pliocene-Pleistocene boundary: Episodes, v. 8, no. 2, p. 116-120.

Baksi, A. K., 1989, Reevaluation of the timing and duration of extrusion of the Imnaha, Picture Gorge, and Grande Ronde Basalts, Columbia River Basalt Group. In Reidel, S.P.; Hooper, P. R., editors, Volcanism and tectonism in the Columbia River flood-basalt province: Geological Society of America Special Paper 239, p. 105-111.

Beeson, M. H.; Fecht, K. R.; Reidel, S. P.; Tolan, T. L., 1985, Regional correlations within the Frenchman Springs Member of the Columbia River Basalt Group: New insights into the middle Miocene tectonics of northwestern Oregon: Oregon Geology, v. 47, no. 8, p. 87-96.

Choiniere, S. R.; Swanson, D. A., 1979, Magnetostratigraphy and correlation of Miocene basalts of the northern Oregon coast and Columbia Plateau, southeast Washington: American Journal of Science, v. 279, no. 7, p. 755-777.

Dalrymple, G. B., 1979, Critical tables for conversion of $K$-Ar ages from $01 d$ to new constants: Geology, v. 7, no. 11, p. 558-560.

Fecht, K. R.; Reidel, S. P.; Tallman, A. M., 1987, Paleodrainage of the Columbia River on the Columbia Plateau of Washington State--A summary: in Schuster, J. E., ed., Selected papers on the geology of Washington, Washington Division of Geology and earth Resources Bulletin 77, p. 219248.

Foley, L. L., 1982, Quaternary chronology of the Palouse loess near Washtucna, eastern Washington: Western Washington University Master of Science thesis, $137 \mathrm{p}$.

Grolier, M. J.; Bingham, J. W., 1971, Geologic map and sections of parts of Grant, Adams, and Franklin Counties, Washington: U.S. Geological Survey Miscellaneous Geologic Investigations Map I-589, 6 sheets, scale $1: 62,500$. (Sheet 5)

Gulick, C. W., compiler, 1990a, Geologic map of the Moses Lake 1:100,000 quadrangle, Washington: Washington Division of Geology and Earth Resources Open File Report 90-1, 9 p., 1 plate.

Gulick, C. W., compiler, 1990b, Geologic map of the Ritzville 1:100,000 quadrangle, Washington: Washington Division of Geology and Earth Resources Open File Report 90-2, 7 p., 1 plate.

Hagood, M. C., 1986, Structure and evolution of the Horse Heaven Hills in South-central Washington: Rockwell Hanford Operations Report RH)-BW-SA344P, 99p, 5 appendices, 1 plate.

Hooper, P. R.; Webster, G. D.; Camp, V. E., 1985, Geologic map of the Clarkston 15 minute quadrangle, Washington and Idaho: Washington Division of Geology and Earth Resources Geologic Map GM-31, 11 p., 1 plate, scale 1:48,000. 
Kittleman, L. R., 1973, Mineralogy, correlation, and grain-size distributions of Mazama tephra and other postglacial pyroclastic layers, Pacific Northwest: Geological Society of America Bulletin, v. 84, no. 9, p. 2957-2980.

Lindsey, K. A., 1991, Revised stratigraphy for the Ringold Formation, Hanford site, south-central, Washington: Westinghouse Hanford CO. WHC-SD-EN-EE$004,12 \mathrm{p}$.

Martin, B. S., 1989, The Roza Member, Columbia River Basalt Group; Chemical stratigraphy and flow distribution. In Reidel, S. P.; Hooper, P. R., editors, Volcanism and tectonism in the Columbia River flood-basalt province: Geological Society of. America Special Paper 239, p. 85-104.

McDonald, E. V.; Busacca, A. J., 1989, Record of pre-late Wisconsin floods and of late Wisconsin flood features in the Cheney-Palouse scabland--Trip $C$. In Joseph, N. L.; and others, editors, Geologic guidebook for Washington and adjacent areas: Washington Division of Geology and Earth Resources Information Circular 86, p. 337-346.

McKee, E. H.; Swanson, D. A.; Wright, T. L., 1977, Duration and volume of Columbia River basalt volcanism, Washington, Oregon, and Idaho [abstract]: Geological Society of America Abstracts with Programs, $v$. 9, no. 4, p. 463-464.

Montanari, Alessandro; Drake, Robert; Bice, D. M.; Alvarez, Walter; Curtis, G. H.; Turrin, B. D.; DePaolo, D. J.., 1985, Radiometric time scale for the upper Eocene and 01 igocene based on $\mathrm{K} / \mathrm{Ar}$ and $\mathrm{Rb} / \mathrm{Sr}$ dating of volcanic biotites from the pelagic sequence of Gubbio, Italy: Geology, v. 13, no. 9 , p. 596-599.

Mullineaux, D. R.; Wilcox, R. E.; Ebaugh, W. F.; Fryxel1, Roald; Rubin, Meyer, 1978, Age of the last major scabland flood of the Columbia Plateau in eastern Washington: Quaternary Research, v. 10, no. 2, p. 171-180.

Myers, C. W.; Price, S. M.; and others, 1979, Geologic studies of the Columbia Plateau--A status report: Rockwell Hanford Operations RHO-BWI-ST-4, 541 p., 53 plates. (Plates II-7 and II-16, scale 1:250,000; Plate III-1 (12 sheets), scale $1: 62,500$ )

Reidel, S. P., 1983, Stratigraphy and Petrogenesis of the Grande Ronde Basalt from the Deep canyon Country of Washington Oregon, and Idaho: Geological Society of America Bulletin, v.94., p.519-542.

Reidel, S. P., 1984, The Saddle Mountains -- the evolution of ananticline in the Yakima Fold Belt: American Journal of Science, v. 284, no. 8, $p$. 942-978.

Reidel, S. P., 1987, Geologic Map of the Saddle Mountains, Southcentral Washington: Washington Division of Geology and Earth Resources, GM-37, 5 plates, scale 1:40,000. 
Reidel, S. P.; Fecht K. R.; 1981, Wanapum and Saddle Mountains Basalts of the Cold Creek Sybcline: in Myers, C. W. and Price, S. M., Subsurface Geology of the Cold Creek Syncline, Rocke1l Hanfford Operations Report RHO-BWI-ST-14, p. 3-1 to 3-45.

Reidel, S. P.; Fecht K. R., 1987, The Huntzinger flow: Evidence of surface mixing of the Columbia River Basalt and its petrogenetic implications: Geological Society of America Bulletin, v. 98, No. 6, p. 664-677.

Reidel, S. P.; Scott G. R.; Bazard D. R.; Cross R. W.,Dick, Brian, 1984, Post-12 million year clockwise rotation in the central Columbia Plateau, Washington: Tectonics, v. 3, no. 2, p. 251-273.

Reidel, S.P.; Tolan T. L.; Hooper P. R.; Beeson M. H.; Fecht K. R.; Bentley R. D., Anderson, J. L., 1989a, The Grande Ronde Basalt, Columbia River Basalt Group - stratigraphic descriptions and correlations in Washington, Oregon, and Idaho, in Reidel, S.P., and Hooper, P.R., eds., Volcanism and tectonism in the Columbia River flood-basalt province: Boulder, Colorado, Geological Society of America Special Paper 239, p. 21-53.

Reidel, S.P.; Fecht, K. R; Hagood, M. C.; and Tolan, T. L., 1989b, The geologic evolution of the central Columbia Plateau, in Reidel, S.P., and Hooper, P.R., eds., Volcanism and tectonism in the Columbia River floodbasalt province: Boulder, Colorado, Geological Society of America Special Paper 239, p. 247-264.

Reidel, S. P.; Hooper, P. R.; Webster G. D.; Camp V. E., 1992, Geologic Map of Southeastern Asotin County, Washington: Washington Division of Geology and Earth Resources Gelogic Map GM-40.

Rietman, J. D., 1966, Remanent magnetization of the late Yakima Basalt, Washington State: Stanford University Doctor of Philosophy thesis, 87 p.

Rigby, J. G.; Othberg, K. L.; Campbe11; N. P.; Hanson, L. G.; Kiver, E. P.; Stradling, D. F.; Webster, G. D., 1979, Reconnaissance surficial geologic mapping of the late Cenozoic sediments of the Columbia Basin, Washington: Washington Division of Geology and Earth Resources Open File Report 79-3, 94 p., 11 plates. (Plate 7, scale 1:250,000, is the same map as Campbel1 and others, 1979.)

Ringe, L. D., 1970, Sub-loess basalt topography in the Palouse Hills, southeastern Washington: Geological Society of America Bulletin, v. 81, no. 10, p. 3049-3059.

Salvador, Amos, 1985, Chronostratigraphic and geochronometric scales in COSUNA stratigraphic correlation charts of the United States: American Association of Petroleum Geologists Bulletin, v. 69, no. 2, p. 181-189.

Stoffel, K. L, 1984, Geology of the Grande Ronde lignite field, Asotin County, Washington: Washington Division of Geology and Earth Resources Report of Investigations 27,79 p., 1 plate, scale $1: 48,000$. 
Swanson, D. A.; Helz, R. T., 1979, Bedrock geologic map of the vent system for the Ice Harbor Member of the Saddle Mountains Basalt, Ice Harbor Dam-Basin City area, southeast Washington: U.S. Geological Survey Open-File Report 79-292, 8 sheets. (Geologic maps: Sheets 4-8, scale $1: 24,000$.)

Swanson, D. A.; Wright, T. L.; Helz, R. T., 1975, Linear Vent Systems and Estimated Rates of magma Production and Eruption for the Yakima Basalt on the Columbia Plateau: American Journal of Science, v. 275, p. 977905.

Swanson, D. A.; Wright, T. L.; Camp, V. E.; Gardner, J. N.; Helz, R. T.; Price, S. M.; Reidel, S. P.; Ross, M. E., 1980, Reconnaissance geologic map of the Columbia River Basalt Group, Pullman and Walla Walla quadrangles, southeast Washington and adjacent Idaho: U.S. Geological Survey Miscellaneous Investigations Series Map I-1139, 2 sheets, scale $1: 250,00$.

Swanson, D. A.; Wright, T. L.; Hooper, P. R.; Bentley, R. D., 1979, Revisions in stratigraphic nomenclature of the Columbia River Basalt Group: U. S. Geological Survey Bulletin 1457-G, 59 p., 1 plate.

Swanson, D. A.; Wright, T. L., 1983, Geologic map of the Wenaha Tucannon Wilderness, Washington and Oregon: U. S. Geological Survey

Miscellaneous Field Studies Map MF-1536, 1 sheet, scale 1:48,000.

Tabor, R. W.; Waitt, R. B., ; Frizzel1, V. A., Jr.; Swanson, D. A.; Byerly, G. R.; Bentley, R. D., 1982, Geologic map of the Wenatchee 1:100,000 quadrangle, central Washington: U.S. Geological Survey Miscellaneous Investigations Series Map I-1311, 26 p., l plate, scale 1:100,000.

Tolan, T. L.; Reidel, S. P.; Beeson, M. H.; Anderson, James Lee; Fecht, K. R.; Swanson, D. A., 1989, Revisions to the estimates of the areal extent and volume of the Columbia River Basalt Group. In Reide1, S. P.; Hooper, P. R., editors, Volcanism and tectonism in the Columbia River flood-basalt province: Geological Society of America Special Paper 239, p. 1-20.

Waggoner, S. Z., compiler, 1990, Geologic map of the Rosalia 1:100,000 quadrangle, Washington-Idaho: Washington Division of Geology and Earth Resources Open File Report 90-7, 20 p., 1 plate.

Waitt, R. B., 1980, About forty last-glacial Lake Missoula jökulhlaups through southern Washington: Journal of Geology, v. 88, no. 6, p. 653-679. 


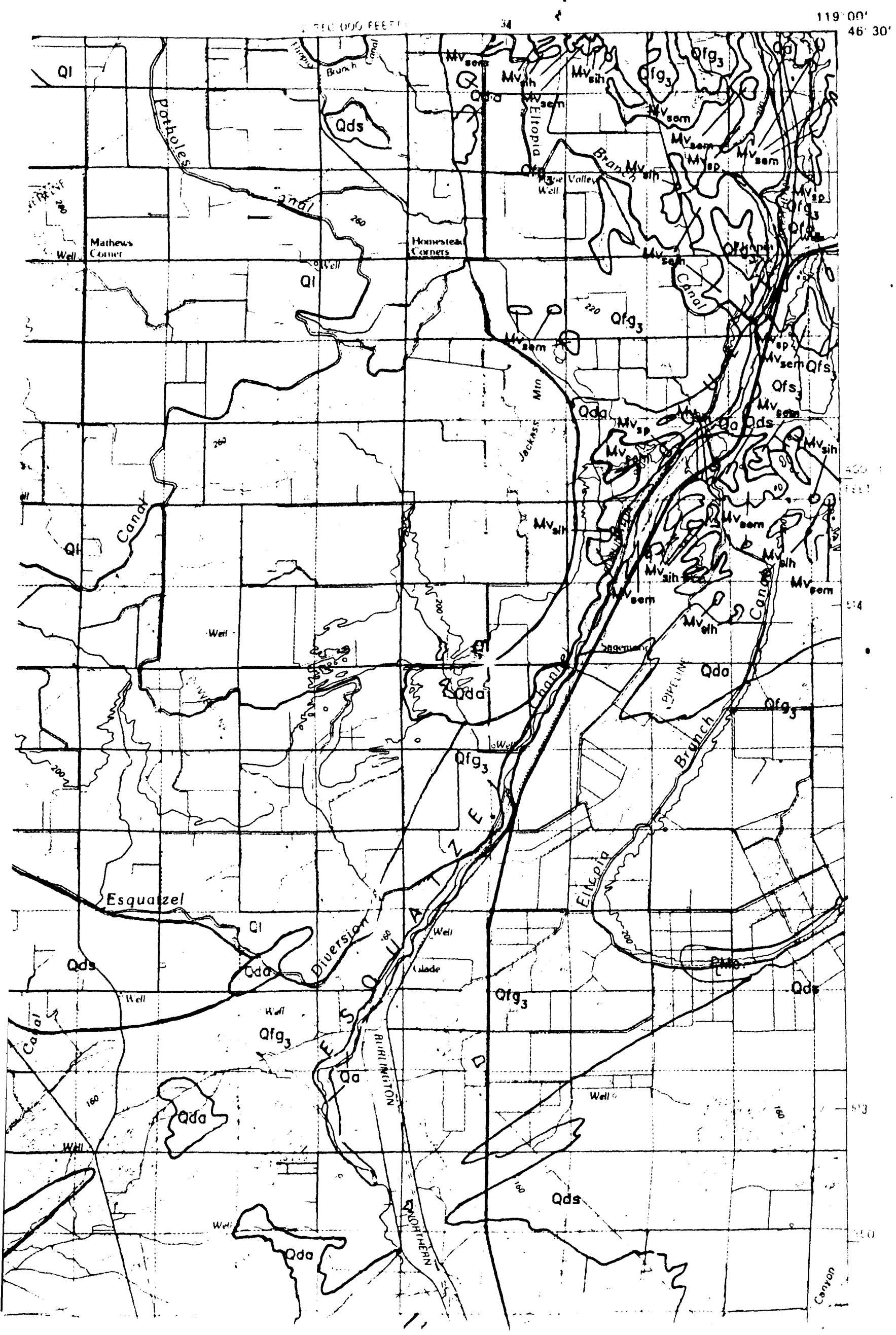




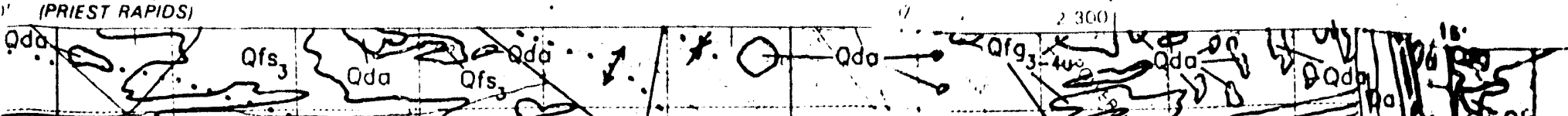

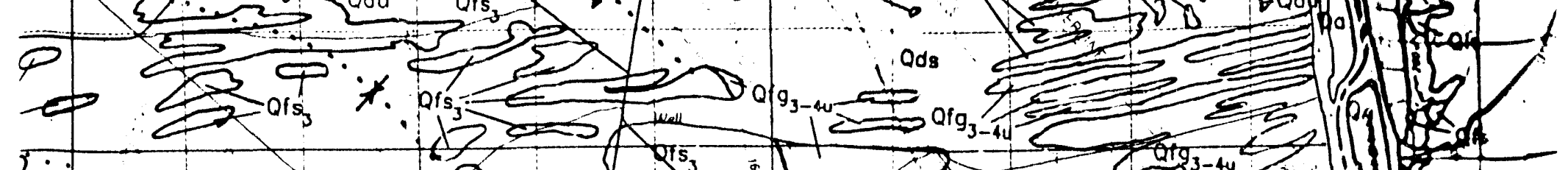
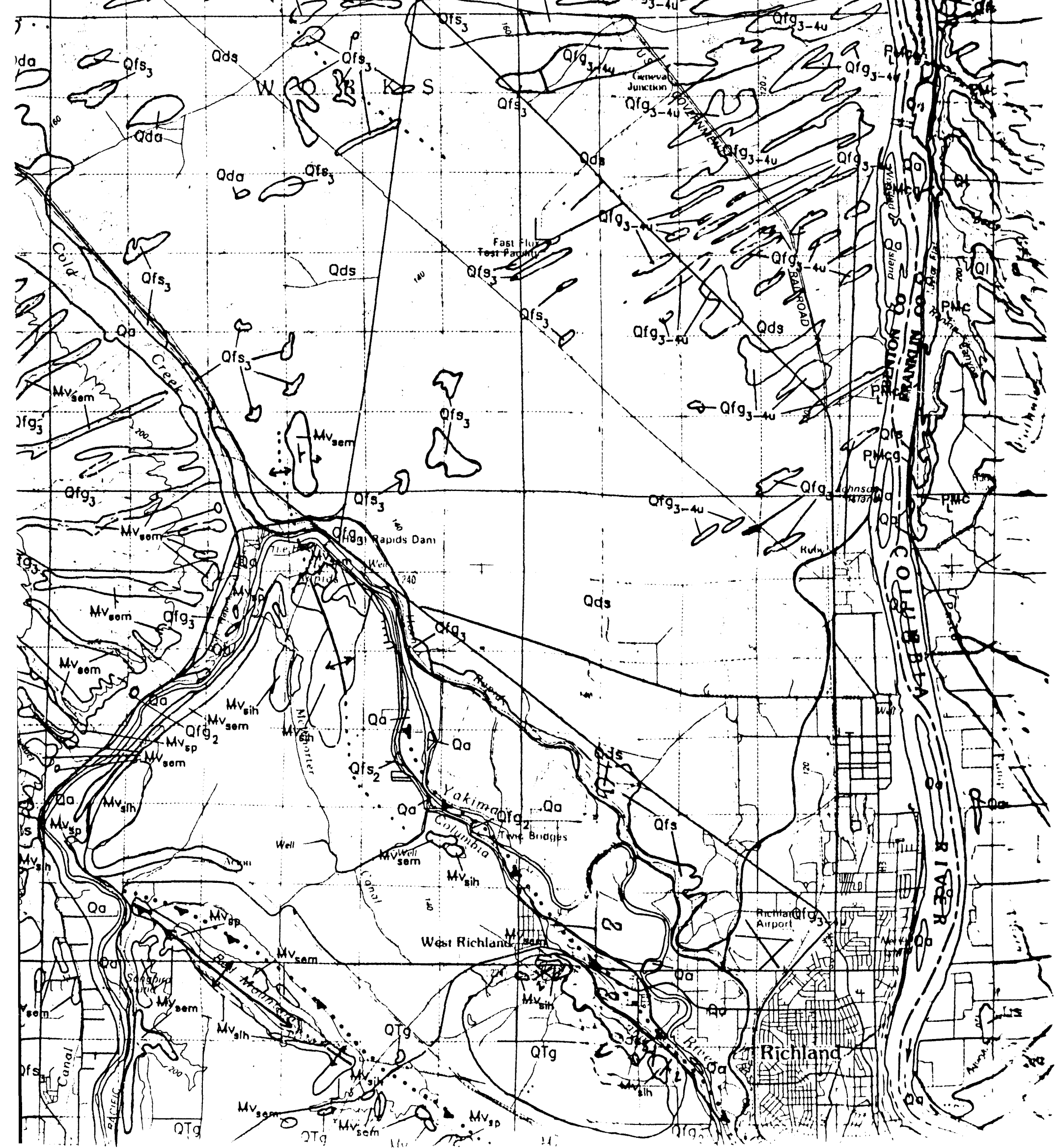


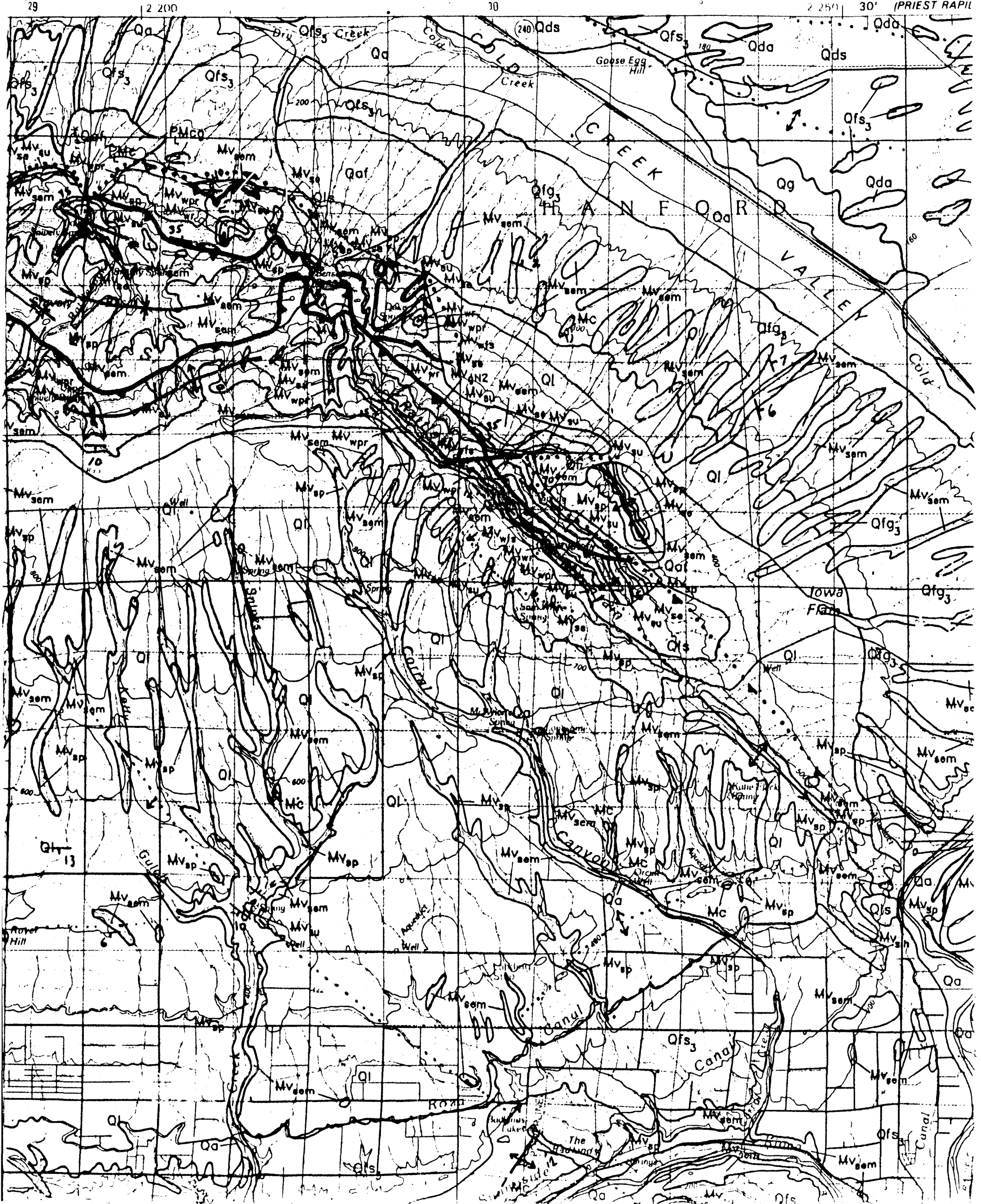


(3)

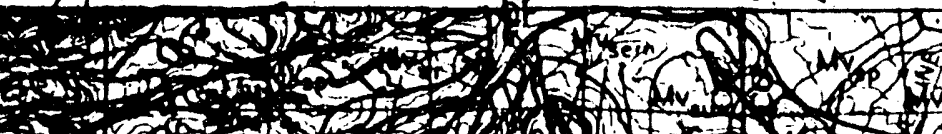
(3) (4)

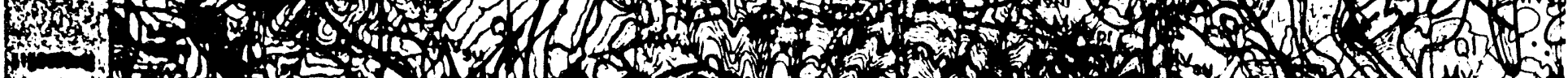

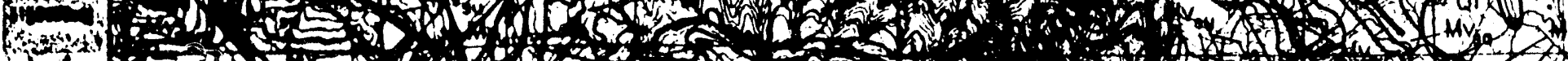

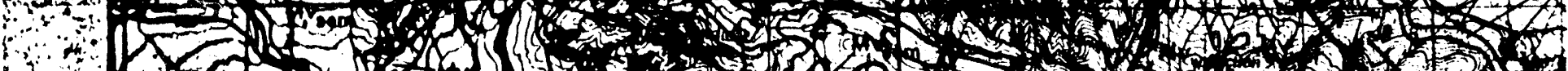

(n)

(2)

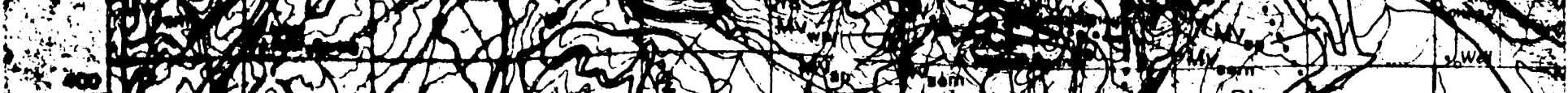

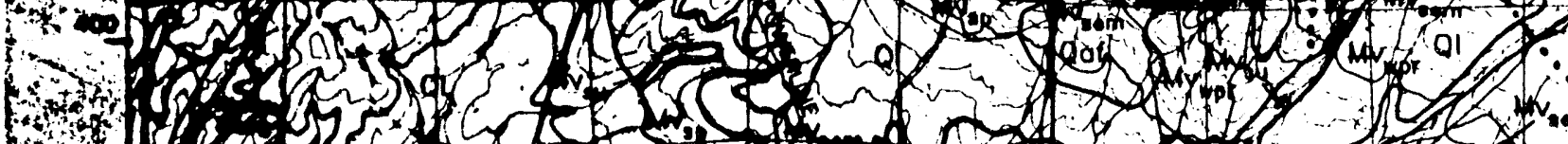

mans

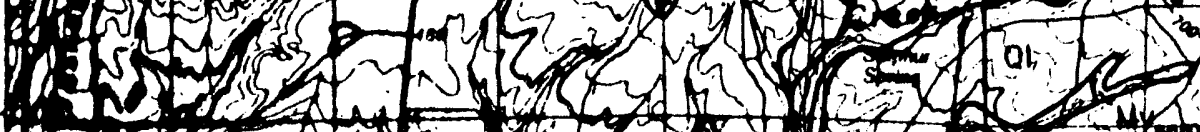

1.5.

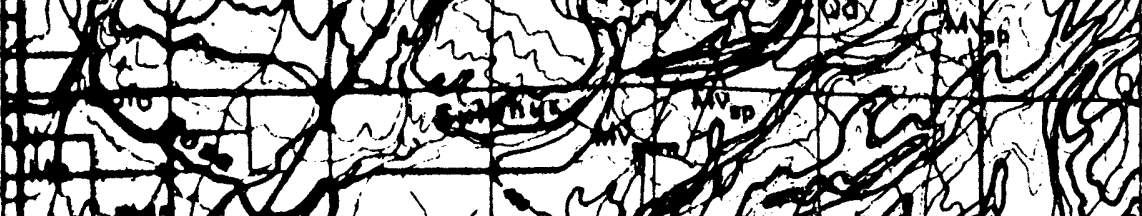

ind

.

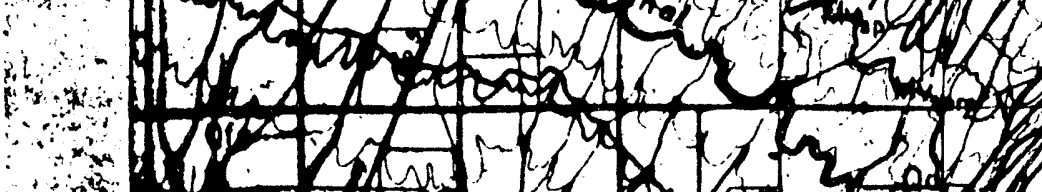
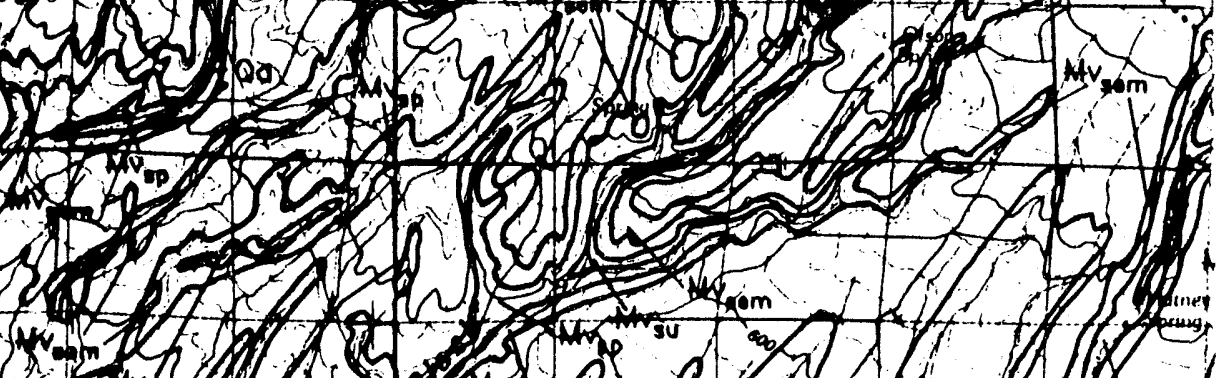

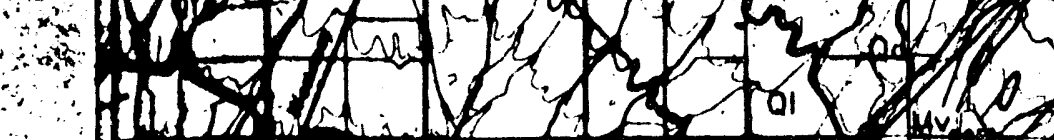

-

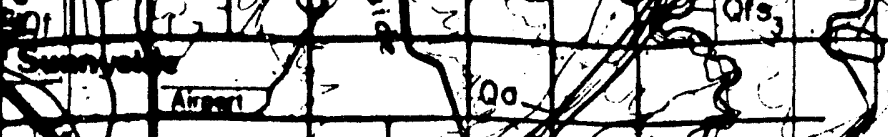

is

isf

$\lim _{0} \mathrm{~S}$

\& fíbe

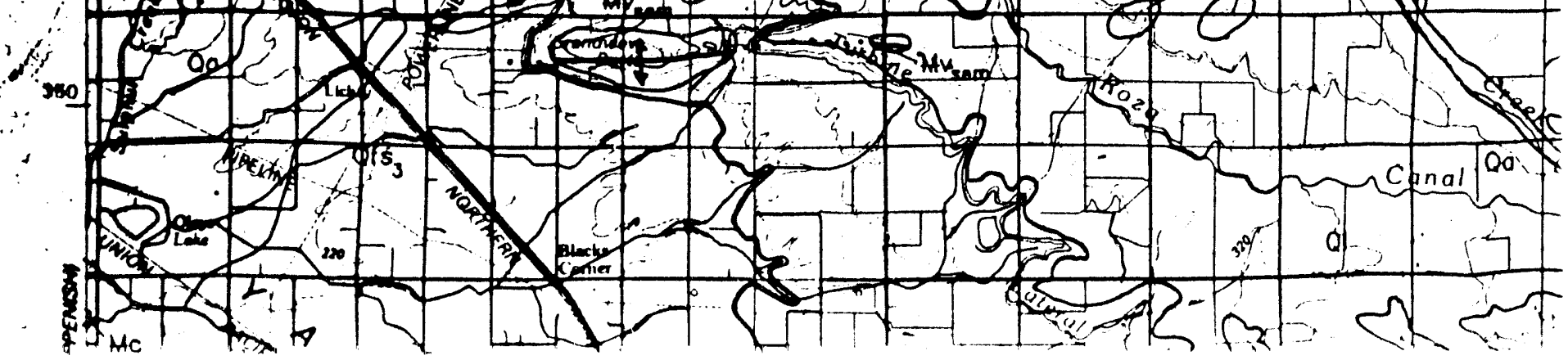




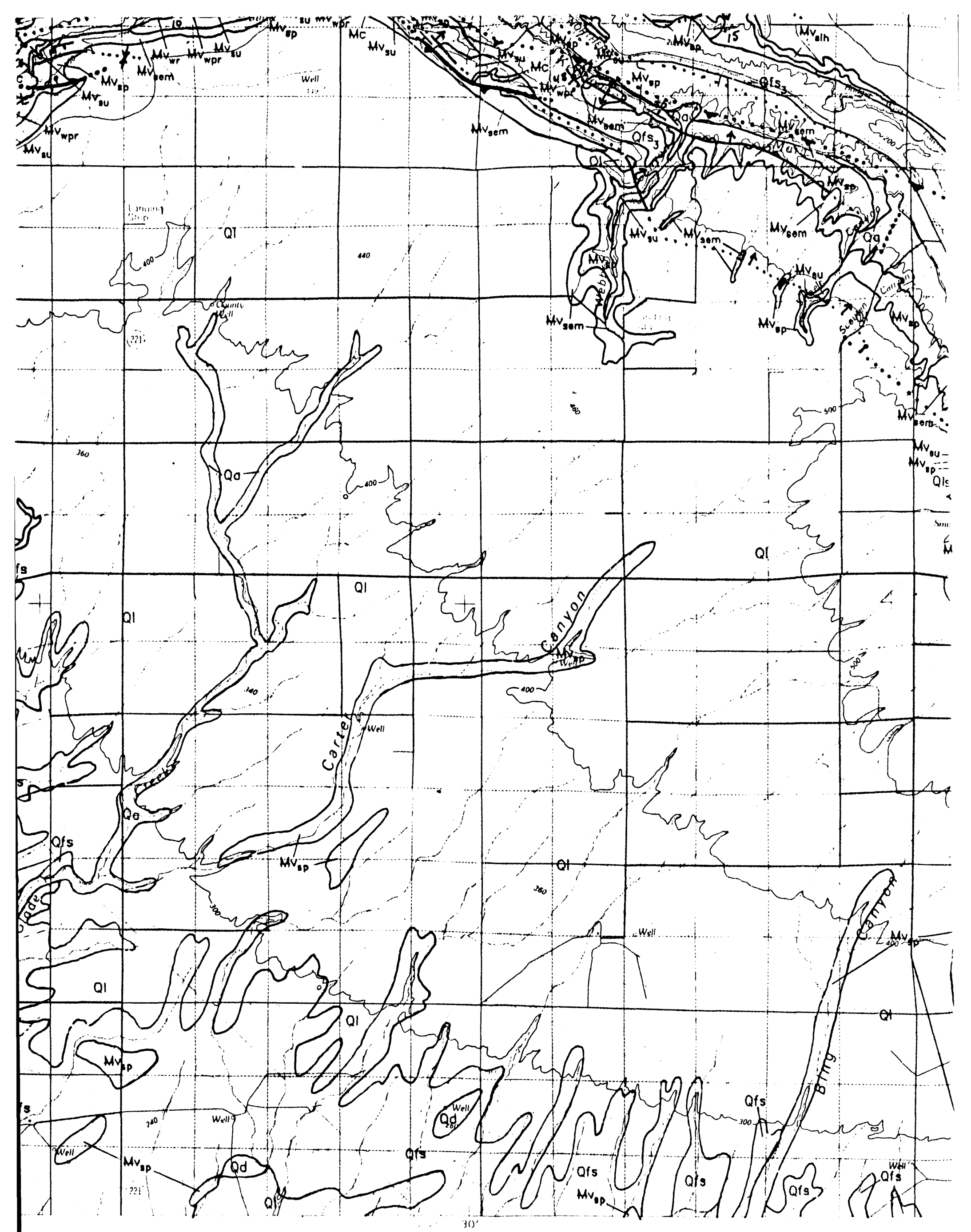




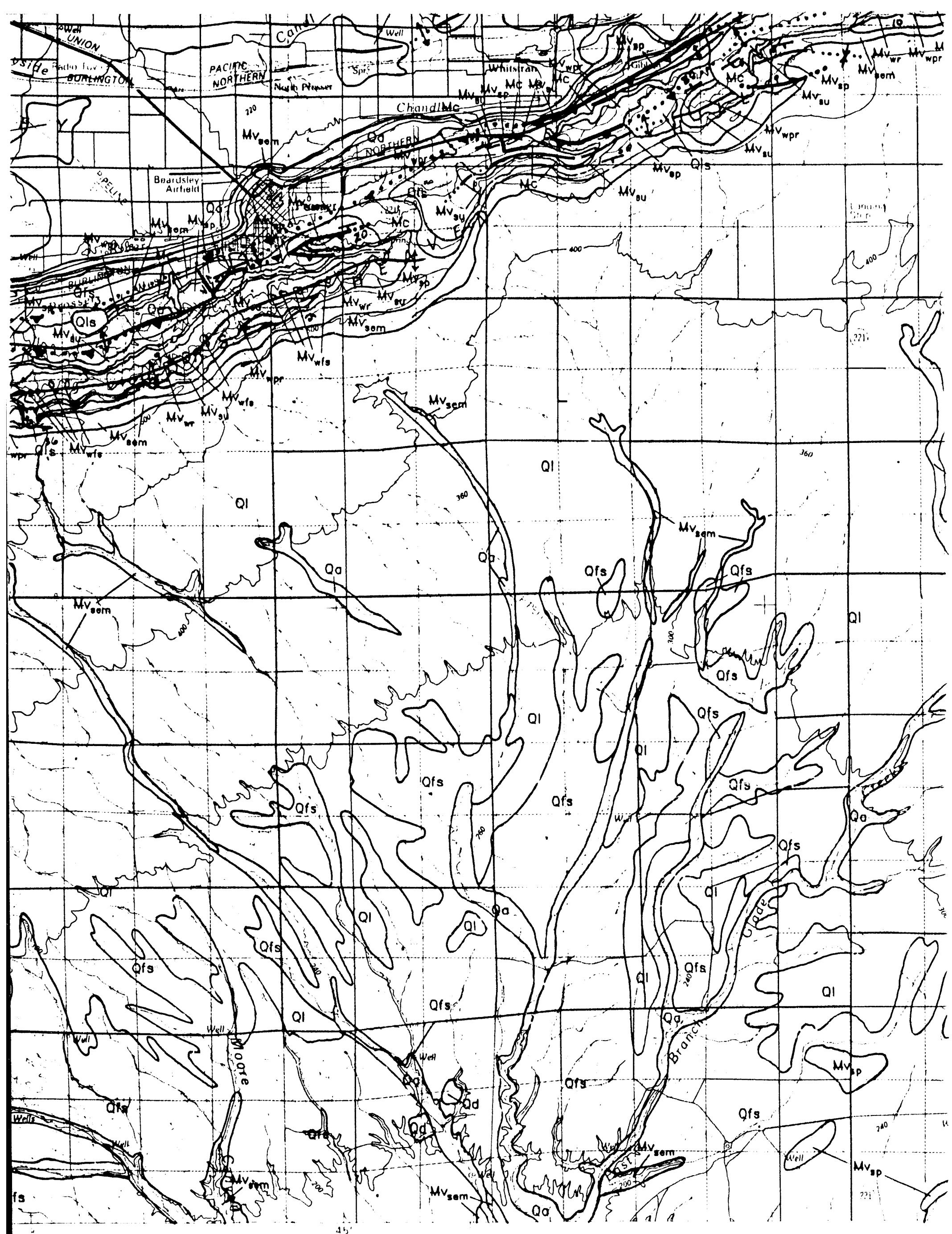



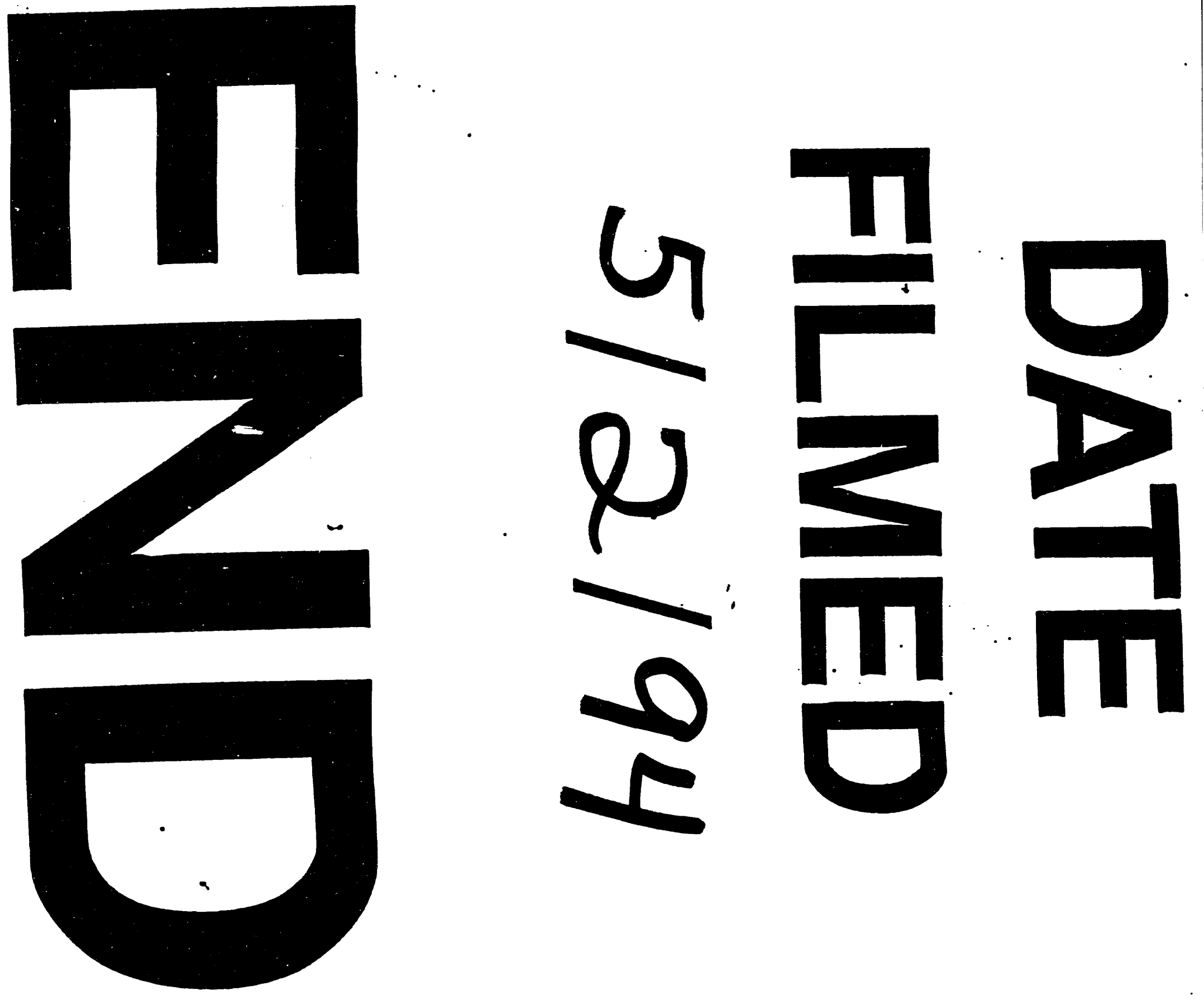


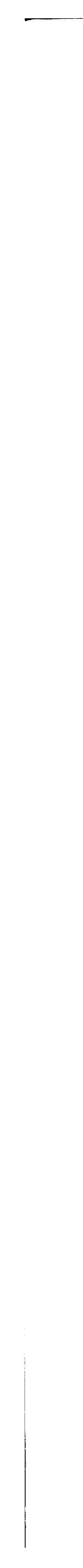

